\section{PRODUCTION}

ENGINEERING ARCHIVES
2014, Vol. 5, No 4, pp 22-25

ISSN 2353-5156

ISSN 2353-7779 (print version)

(online version)

Article history: $\quad$ Received: 07.11.2014

\title{
ISO/TS 16949 system in quality aspect
}

\author{
Joanna Rosak-Szyrocka ${ }^{1}$, Stanisław Borkowski ${ }^{2}$ \\ ${ }^{1} \mathrm{PhD}$., Czestochowa University Of Technology, Faculty Of Management,Institute Of Engineering Production, e-mail: asros@op.pl \\ ${ }^{2}$ Multi Prof. dr hab. inż., Czestochowa University Of Technology, Faculty Of Management,Institute Of Engineering Production,e-mail: \\ bork@zim.pcz.pl
}

\begin{abstract}
In the automotive industry the use of modern technology and provision of the highest quality product and related services is the most important element of rivalry between global corporations and motorcycles. In a competitive struggle for the recognition of its brand in the automotive market global organizations continuously raise the requirements for quality management systems, so that the finished product meets all the standards in terms of safety, quality and satisfying the ever-growing needs of customers - present and future drivers and passengers of cars. ISO/TS 16949 quality management system is presented in the paper. A framework for customer specific requirement as well as preventing problems is shown.
\end{abstract}

Key words - ISO/TS 16949, quality, automotive industry

\section{Introduction}

In the business world in which competition is becoming ever more cutthroat, quality is one of the most important elements. Modern organizations should focus on quality, regardless of the type of business, because it is the most basic form of an effective business It is not only a factor of market success, but also the indication of organization culture (BORKOWSKI S., ROSAK-SZYROCKA J. 2009).

Competition for clients in the automotive market, adapting the product to their expectations, as well as a philosophy of continuous improvement, helps to make frequent changes in individual quality management systems of global car companies (ROBAK B., ULEWICZ R. 2013).

"Revolutions" car manufacturers in quality management systems, causing difficulties in managing the factory system documentation, was often carried out for several different independent quality management systems, such as working with Renault, BMW and Ford organization had to have three implemented quality management systems: EAQV (French quality management system), VDA 6.1 (German quality management system), QS-9000 (U.S. quality management system).

Because of the difficulties which are encountered in the management of the company quality systems and visible qualitative differences occurring in car companies in 1999, it was decided to create a single platform requirement for all suppliers of the automotive market (CVAHTE T., ŠKORNIK M., JANČAR, R., JEREB B. 2011).

\section{ISO/TS 16949 characteristic}

Apart from the individual automotive quality management systems characteristic to particular car companies, the basic standard currently used in the internation- 
al automotive markets is the quality management system based on the ISO/TS 16949 technical specification.

ISO/TS 16949 together with ISO 9001 is posing guidelines for the implementation and maintenance of quality management systems in the whole chain of production processes and the production of spare parts in the automotive industry.

The ISO/TS 16949 standard defining requirements focused on continual improvement, and the understanding of process interaction. It also creates an implementation framework for customer specific requirements, and includes clear requirements for development processes, and techniques to prevent problems in the earliest possible stage of product development (www.dnvba.com).

The initiator of this project was the IATF (International Automotive Task Force - International Operations Team Industry Automotive) and national trade associations (AIAG - America, VDA - Germany, SMMT - United Kingdom, ANFIA - Italy, FIEV France). This was responsible for the design of the technical group International Organization for Standardization ISO TS 176 that as a result of heated debates set a new standard ISO / TS 16949 "Quality systems for suppliers to the automotive market - the specific assumptions for ISO 9001:1994." his intention was to harmonize the requirements of the quality management systems of the automotive market: the U.S. (SQ 9000), Italian (AYSOJ, French (EAQV) and German (VDA 6.1) with ISO 9001:1994. The message of ISO/TS 16949:1994 was to ensure continuous improvement, prevent defects, reduction of volatility and losses in the supply chain.

It was initially presented as an alternative to those organizations that were certified to US9000, VDA 6.1, AVSQ and EAQF. However, with the retirement of QS 9000, AVSQ and EQFQ in recent years, more and more companies have chosen to be certified with ISO/TS 16949 (BORKOWSKI S., ULEWICZ R. 2001; BORKOWSKI S., ULEWICZ R. 2000).

It is an industry specific Quality Management System (QMS) catering for automotive industries with the following objectives: promoting continual improvement; emphasising defect prevention; continual wastage and variation reduction.

The Standard is based on ISO 9001:2008 standard with additional common automotive industry require- ments. The requirements are encompassed in 5 clauses, namely: Quality Management System; Management Responsibility; Resource Management; Product Realization; Measurement, Analysis \& Improvement.

Key guidelines for implementing ISO/TS 16949 are the following (ŁYSAK D. 2013):

1. Make sure your whole business and supply chain are committed.

2. Engage your business and supply chain with good communication.

3. Compare existing quality management with ISO/TS 16949 requirements.

4. Get supply chain and stakeholder feedback on current quality processes.

5. Establish an implementation team to get the best results.

6. Map out and share roles, responsibilities and timescales.

7. Adapt the basic principles of the ISO/TS 16949 standard to your business.

8. Motivate staff and supply chain involvement with training.

9. Encourage your supply chain to become ISO/TS 16949 certified.

10. Regularly review your ISO/TS 16949 system to make sure it remains effective and that you are continually improving it.

\section{Management system implementation}

Implementation of ISO/TS 16949 management system is by no means an easy task. Organizations that have chosen the DIY (Do-It-Yourself) approach may find it confusing when upgrading their ISO 9001 management system to ISO/TS 16949 which includes additional automotive industry requirements and customerspecific requirements. For a company of around 100 staff, it will probably take close to a year to ready itself for the certification process. Even though ISO 9001 is not a pre-requisite for ISO/TS 16949, it is recommended to be implemented first.

To be effective, a project team that consists of a team leaders and members from the key processes should be formed to spearhead the project. Usually, in the initial phase, the team will spend almost 50\% of their working time devoted to this purpose. Additional costs could come from the additional staff em- 
ployed to temporarily take over the duties of the team members assigned.

Engaging a consultant will probably help the organization to avoid many problem or pitfalls when the organization is trying to implement the system itself. Consultants with years of experience in auditing and consulting will be able to advise the organization how to effectively implement the management system. However, a word of caution - the organization should always maintain ownership of the system - not the consultant. In many cases, where the consultant is left alone to develop and implement the entire management system and after certification is complete, the organization will realize they have no idea how to maintain the system.

The consultancy costs will depend on the certification scope, number of site and remote locations. It is always a good idea to obtain a few quotations from a number of reputable consultancy firms for comparison before a final decision is made. The price should not necessarily be the deciding factor as sometimes the track record and the consultant's professionalism are the more important factors to be considered.

The costs of certification for ISO/TS 16949 are dependent on the scope of certification, size of the organization, number of manufacturing sites and remote locations. IATF through its "Rules for Achieving Recognition" states the audit man-day requirement be based on the number of employees in the organization. Most of the certification bodies follow the rules quite closely in quoting audit man-days for the organization. Certification bodies usually charge a certain day rate for the audit performed and the rate can be quite different among different countries and different certification bodies (http://www.kantnercompany.com/aa16949. kc.htm, HoYLE D. 2005, NeSS R. 2003).

\section{ISO/TS 16949 in Poland}

In Poland, the first quality systems began to be implemented in the 90's. The first companies that have decided to change the approach to quality have been exporting their products to EU countries. Boards of these companies wanted above all to enter new markets. So it was the main, and often only, goal. However, after a few years, a large group of companies began to implement quality systems in accordance with ISO 9000 with a view to acting on the Polish market. Their goals were similar to those of the leading European companies: reduce costs, increase competitiveness and internal benefits. Soon, however, came an entrepreneur looking for a shorter route through the purchase documentation or even purchase certificate. These, however, are not enough, most of the management decided to implement the system consciously aware of the benefits to be gained. At the end of June 2010, a total of 42,189 certificates were issued to ISO/TS 16949.

\section{Summary}

Global companies and their suppliers who want to be competitive in the automotive market must continually evolve. A requirement for the production of the product with the highest standards, beyond the use of the most modern technological methods, is the implementation of quality management systems and their continuous improvement in organizations using qualitative methods.

The automotive industry, in an era of increasing technological advances, increasing awareness of quality requirements of customers and a constantly changing market situation, requires vehicle manufacturers to guarantee the best quality methods implemented product. There are internal and external benefits of certification. The external benefits of an ISO/TS 16949 quality management system are the following:

Satisfies the demands of current or prospective customers for registration.

Improves customer focus. Controls are focused on management of the processes that enable the company to achieve and improve customer satisfaction.

Boost international acceptance and credibility. ISO/TS 16949 is in fact an international quality management specification. It is known, recognized, and accepted without question all over the world.

Places company in an elite category of businesses. Registration to ISO/TS 16949 puts an organization on a level of excellence shared by organizations of all kinds worldwide.

Prepared for external audits and inspections i.e. regulators, customers, etc.

\section{Facilitates continual improvement.}




\section{Provides competitive advantage.}

The internal benefits of an ISO/TS 16949 quality management system are the following (ROSAKSZYROCKA J., BORKOWSKI S. 2014; SMITH R.M., MUNRO R.A., R.J. 2004; CHAD K. 2004 ):

Transforms operation from detection mode to prevention mode. Prevention is less work and less expense than detection. With an ISO/TS management system, some prevent product non-conformities, prevent pollution by addressing the causes and mitigate or eliminate hazards and risks to protect the health and safety of employees and others.

Creates consistency throughout the organization built around "best practices".

Improves business performance. A well designed, well implemented ISO compliant management system can help improve satisfaction of customers and consumers; and boost internal manufacturing and operational efficiencies.

Lessens dependency on key individuals. An ISO management system distributes responsibility and accountability across the work force. More people share more information and accountability for key quality tasks. Result: tasks or processes don't collapse just because one person leaves or changes jobs. And each person carries his or her small share of the load.

Provides blueprint for controlled, disciplined growth. Some organizations see ISO/TS management systems as a way to organize the business, systematize practices, and ensure management accountability as the organization expands.

Ensures consistent training. An ISO system is like a collection of road maps. Each road map provides direction from one end of a process to the other.

Improves management oversight. An effective ISO management system incorporates monitoring and measurement of key performance indicators in quality and customer satisfaction. This gives management objective data upon which to base decisions. The required self-auditing function is even more powerful. Internal auditing is an "early warning system" to help spot process problems and potential customer satisfaction issues - giving the chance to address and resolve them before they are detected by others, rather than after. Then management review, closing the loop, providing management with solid data, enabling man- agement to make decisions based on facts and evidence.

\section{References}

1. BorkowsKi S., RoSAK-SZYROCKA J. 2009. Procedury uzyskiwania znaków jakości, Wydawnictwo Politechniki Częstochowskiej, Częstochowa.

2. BORKOWSKI S., UlEWICZ R. 2000. The application of analytical methods in solving quality issues and quality improvement in the automotive industry, Advanced Manufacturing and Repair Technologies in Vehicle Industry.17th International Colloquium.Zielona GóraŁagów.

3. BorKOWSKI S., UlEWICZ R. 2001. The Quality System According to the Norm QS-9000, MT'01.The Third International Conference. Mechanical Engineering Technologies. Sofia.

4. СHAD K. 2004. The ISO/TS 16949 Implementation Guide, Paton Press, LLC, ISBN 1-92-2828 - 01-X.

5. CVAHTE T., ŠKORNIK M., JANČAR, R., JEREB B. 2011. Guidelines for supply chain risk management. V: GUMZEJ, Roman (ur.). Enhancing the service quality in autonomous systems : proceedings of the Laško workshop. Celje: Fakulteta za logistiko, 2011, str. 61-69, graf. prikazi, tabele COBISS.SI-ID 512316733.

6. HOYLE D. 2005. Automotive Quality Systems Handbook, Second Edition: ISO/TS 16949:2002 Edition, Linacre House, Jordan Hill, Oxford, ISBN 0750666633.

7. http://www.kantnercompany.com/aa16949.kc.htm.

8. http://www.standards.org/standards/listing/iso_ts_16949.

9. ŁYSAK D. 2013. Specyfikacja techniczna ISO/TS 16949, Problemy Jakości 10.

10. NeSS R. 2003. Practical Auditing Techniques for ISO/TS 16949, Printed in USA, ISBN 0-595-27312-2.

11. SMITH R.M., MUNRO R.A., R.J. 2004. The ISO/TS 16949 Answer Book, Paton Press, LLC, ISBN 1-932828-00-1.

12. ROBAK B., UleWICZ R. 2013. Use of selected instruments to solve quality problems in the automotive industry. Chapter 16. Product Quality Improvement and Companies' Competitiveness. Monography. Editing and Scientific Elaboration Stanisław Borkowski, Manuela Ingaldi, Faculty of Logistics, University of Maribor, Celje.

13. ROSAK-SZYROCKA J., BORKOWSKI S. 2014. Automotive Quality Management Standard ISO/TS 16949 in the Competitive Aspect. Analysis of Technology in Various Industries. Monography. Scientific Editors Borkowski, S., Ulewicz R., Oficyna Wydawnicza Stowarzyszenia Menedżerów Jakości i Produkcji, Częstochowa, ISBN 978-83-63978-11-2.

14. www.dnvba.com. 
Joanna Rosak-Szyrocka, Stanisław Borkowski: ISO/TS 16949 system in quality aspect, Vol. 5(4)/2014 